\title{
Protective membranes at electrochemical biosensors
}

\author{
Anton Ambrózy, Lenka Hlavatá, Ján Labuda \\ Institute of Analytical Chemistry, Faculty of Chemical and Food Technology, \\ Slovak University of Technology in Bratislava, Radlinského 9, SK-812 37 Bratislava, Slovak Republic \\ anton.ambrozy@stuba.sk
}

\begin{abstract}
The primary role of the biosensor is to specifically detect an analyte using biochemical reaction or interaction mediated by isolated biomolecules, organelles, whole cells or biomimetic receptors. In terms of construction and function, the biosensor consists of biorecognition element and transducer connected to suitable measurement device. Electrochemical biosensor is an electrode or microelectrode with the surface chemically modified by the biorecognition element. The main problem of analysis with the biosensors is the presence of low and high molecular weight substances in the sample that interfere at the detection of analyte. Due to deposition of surface active compounds the biosensor response may be diminished depending on time of interaction with sample. These effects can be eliminated by using anti-interference membranes. This review deals with preparation and utilization of membranes for the biocomponent immobilization and with outer-sphere protective membranes.
\end{abstract}

Keywords: biosensor, interference, surface active compounds, protective membrane, chemically modified electrode

\section{Introduction}

The main task of modern chemical analysis is to detect and determine small quantities of substances in complex matrices of the samples. Therefore, chemical analysis requires the development and use of new laboratory equipments enabling the effective separation and sensitive detection of individual components in a mixture. Currently, biosensors represent important analytical devices that contain component of biological origin, which in combination with the physicochemical transducer provides required degree of selectivity and sensitivity. The biological component in this system operates on biocatalytic or bioaffinity principle. Biosensors are highly effective in analytical performance at low costs for both obtaining and utilization.

Nowadays, analytical chemistry has a number of instrumental methods enabling the determination of trace concentrations of various analytes in complex mixtures. However, this task requires a complex sample preparation for the analysis, application of suitable separation method, or derivatization of analyte before its sensitive determination. These operations are time-demanding, expensive and do not allow determination of a large number of samples in short time. Use of properly designed biosensors may represent a suitable alternative to the conventional instrumental methods of analysis. Practical use of simple measuring equipment such as laboratory and pocket meters in combination with appropriate biosensors is typical for solving specific tasks in small testing and clinical laboratories and even testing performed in home (e.g. glucometers).

One of the most widespread types of the biosensors is electrochemical (amperometric) biosensor. In practice, it represents a chemically modified electrode, which is made of various forms of carbon, carbon paste or inert metal covered by thin layer of the biocomponent which allows selective capture of the analyte. The rational chemical modification of electrode surface allows change the chemical, electrical, electrochemical, and transport properties of electrode (Labuda 2012). Chemical modifier can be bound to the electrode surface by simple adsorption, cross linking, capturing in the polymer film or by chemical bond.

The use of amperometric biosensors in complex samples can be also problematic as interfering substances contained in the solution to be analyzed may affect the signals. One of the serious problems related to the analysis with the biosensors is the presence of electroactive substances in the sample/ test solution, which undergo electrochemical reaction near to detection potential. Electroactive substances resulting from the biocatalytic reaction can also contribute to inaccuracies of the determination. Another source of interferences is the presence of high molecular weight compounds which block the active surface of the biosensor, typically by their adsorption.

Main objective of rationalized biosensor design is, therefore, achievement of high selectivity associated with elimination of unwanted interferences (McGrath et al. 2012). This goal can be achieved by complex approach used at the biosensor construction. First of all, there are numerous examples of selective effects of mostly polymeric membranes 
utilized for the biocomponent immobilization. Second, there are reports on enzymatic elimination of both small electroactive and large molecules within the protective layer which cover the biocomponent layer. Using appropriate (bio)chemical reaction, interferences are converted/decomposed to a form which does not interfere. For example, covering an amperometric biosensor with pyranose oxidase for the determination of disaccharides by an antiinterferential membrane containing the enzyme hexokinase allowed the elimination of effect of glucose in the presence of ATP by its phosphorylation (Petřivalsky et al. 1994). A similar example represents biosensor with double-stranded DNA and glucose oxidase immobilized on the plane pyrolytic graphite electrode surface as the layer-by-layer assembly (Zu et al. 2009). The catalase layer located in close proximity of DNA ensured the effective DNA protection from damage by $\mathrm{H}_{2} \mathrm{O}_{2}$ produced in situ in the reaction of glucose oxidase with glucose. Third, interferences, particularly high molecular ones, can be separated by outer-sphere protective membranes with size and/or charge exclusion properties. These solutions have been recently reviewed in excellent paper (Zajoncová and Pospíšková 2009).

The aim of this paper is to review progress on this topic and to stimulate further development of the complex construction approach at the biosensors together and further use of biosensors at analysis of clinical, environmental, food, and water samples with complex matrices.

\section{Membranes for the immobilization of biocomponents and electrode protection}

Immobilization of biocomponents within the polymeric membrane belongs to the popular ways of the construction of biorecognition layers. The polymer membrane fulfils several goals from the biomolecule attachment to control of access of both analyte with reagents and electroactive and high molecular interferences.

Probably the most commonly used type of membrane is cellulose-acetate membrane which retained, for instance, molecules larger than 5000 Da and provided reproducible signals of hydrogen peroxide (Alp et al. 2000). Nevertheless this membrane was not able to avoid completely penetration of ascorbic acid to the electrode surface. Other membranes have been based on synthetic polymers (reviewed in Zajoncová and Pospíšková 2009). Nonconductive polymers are characterized by high resistivity, therefore, the membranes created from them should be thinner than, for instance, conductive polymer membranes. The thickness of non-conductive polymer layers varies in nanometers range which allows the diffusion of both hydrogen peroxide to the electrode surface and substrate and product of the biochemical reaction used (Miao et al. 2004). Among phenols, the nonconductive layer of poly(3aminophenol) was suitable at the determination of glucose (Dong-Hun et al. 1995). Polymerization of monomers with appropriate groups allowed covalent attachment of the enzyme to the nonconductive layer. Phenylenediamine such as 1,2diaminobenzene (Somasundrum and Aoki 2002, Yao et al. 2003, Wang et al. 2000) was used in the biosensor for in vivo determination of L-lactate and glucose in rat brain. Recently, a biosensor for the determination of polyphenols was reported with polyphenol oxidase in the membrane prepared by the electropolymerization of 1,2-diaminobenzene on a screen printed Pt electrode of $1 \mathrm{~mm}$ diameter (Akyilmaz et al. 2010). Poly(1,3-diaminobenzene) resulted in the protection of the electrode surface against deposition of macromolecules in plasma, blood serum and urea, but not in blood (Daly et al. 1999). The biosensor with this membrane was used for the determination of creatinine (Madaras and Buck 1996), glutamate (Berners et al. 1994) and lactate (Yang et al. 1997). For glucose oxidase capturing, 1,4-diaminobenzene was also suggested (Xu et al. 2002). The poly(o-phenylenediamine) membrane created on the electrode surface via electropolymerization was employed for the immobilization of lysine oxidase on a $\mathrm{Si}$-gold strip electrode to construct L-Lysine biosensor (Ioannis et al. 2000). The biosensor has a good response against the tyrosine and cysteine, but the response to phenylalanine, arginine, histidine and ornithine was rather low.

Glucose oxidase, lactate oxidase, L-amino acid oxidase and alcohol oxidase were immobilised in the layer based on 2,6-dihydroxynaphthalene electrocopolymerised with 2-(4-aminophenyl)ethylamine on the surface of Pt electrode (Badea et al. 2003). Enzyme entrapment was realized during the process of electropolymerisation by a covalent enzyme fixation to the film via 1-ethyl-3-(3-dimethylaminopropyl) carbodiimide or glutaraldehyde. This biosensor response to hydrogen peroxide, ascorbic acid and acetaminophen was tested using cyclic voltammetry and amperometry.

Increased stability and selectivity of a peroxynitrite $\left(\mathrm{ONOO}^{-}\right)$biosensor was achieved by polyethyleneimine layer which was created on the surface of a new manganese-[poly-2,5-di-(2thienyl)-1 $H$-pyrrole)-1-( $p$-benzoic acid)] complex prepared by the electropolymerization on the $100 \mu \mathrm{m}$ diameter platinum tip and the complexation of $\mathrm{Mn}^{2+}$ ions (Koh et al. 2010). Biosensor was applied in a real rat plasma sample for the detection of spiked concentrations of $\mathrm{ONOO}^{-}$. 
Overoxidized pyrrole allowed determination of glucose in micromolar concentration in the presence of physiological concentrations of ascorbate, urate, cysteine and acetaminophen (Murphy 1998, Centoze et al. 1992, Palmasino et al. 1993, Centonze et al. 1997, Guerriri et al. 1998). The membrane was also utilized at the cholesterol determination in diluted serum (Vidal et al. 1999) and fructose determination in dietetic foods (Garcia et al. 1998).

Substituted naphthalenes like 2,3-diaminonaphthalene, 1,5-diaminonaphthalene, 1,8-diaminonaphthalene, and 5-amino-1-naphthol were shown to protect biosensor against the effects of electroactive substances leading to lowering of signals of hydrogen peroxide as well as ascorbate, urate and acetaminophen (Carelli et al. 1996).

Negatively charged polymer Nafion is widely used as a barrier for diffusion of small neutral or negatively charged interfering species such as ascorbic acid and uric acid. Nafion is biocompatible to the enzymes since it has both hydrophilic and hydrophobic properties, it is chemically inert and exhibits relatively little adsorption of species from the solution.

At a bienzymatic glucose/polyphenol oxidases biosensor with the enzymes immobilized in inorganic laponite gels, the use of polymeric Nafion membrane at the transducer surface reduced effects of electroative interferents such as ascorbate, urate and acetaminophen (Poyrda et al. 1998). Similarly, Nafion was utilized as a protective membrane at the biosensor composed of $\mathrm{SiO}_{2}$ nanosheets-Nafion nanocomposites on the glassy carbon electrode surface and acetylcholinesterase (AChE) crosslinked with chitosan (Yang et al. 2013). The nanocomposites exhibited excellent conductivity, catalytic activity, and biocompatibility and the polymers improved the biosensor stability.

Potentiometric urea biosensor with the enzyme urease resulting to the $\mathrm{CO}_{2}$ formation was constructed using chitosan membrane and the $\mathrm{pH}$ electrode as a transducer (Mulyasuryani et al. 2010). Chitosan membrane with amino groups facilitates interaction with the acid like $\mathrm{CO}_{2}$.

\section{Outer-sphere protective membranes}

For the case that the bioelement immobilization method does not ensure a true biosensor response properly, the use outer-sphere membranes was suggested which avoid access of unwanted mostly high molecular interferences to the electrode surface. In such case, the construction of an electrochemical/amperometric biosensor is a process of the formation of multilayer system. Substrates are transported through external membrane into the biorecognition enzyme matrix by diffusion. Resulting analytical signal is affected by the rates of enzyme (generally biocomponent) reaction and the diffusion which controls the amount of analyte reaching the enzyme matrix.

Generally, there are some requirements on the biosensors with external membranes. They have to:

- be compatible with the environment in which the biosensor works,

- have sufficient lifetime for the analysis of biological samples,

- prevent the growth of microorganism on the surface. The presence of microorganisms leads to excessive consumption of oxygen in the vicinity of the membrane. This process causes insufficient oxygen diffusion into the enzyme layer.

Application of the external membrane for biosensor design improves:

- the response value in the presence of potential interferences,

- linearity of its concentration response and lifetime,

- operation stability in continuous monitoring.

Again, cellulose-acetate membrane was commonly used in a role of protective outer-sphere membrane (Fig. 1).

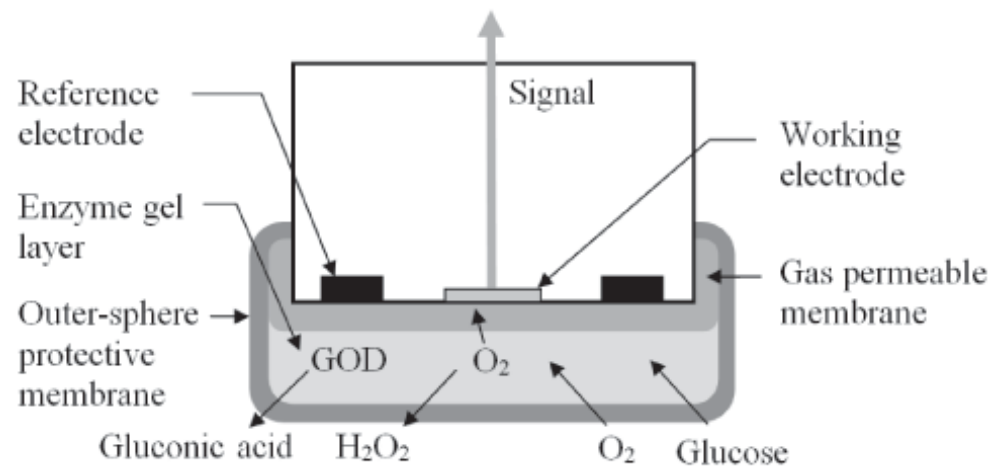

Fig. 1. Scheme of glucose oxidase (GOD) based biosensor with an outer-sphere protective membrane and gas permeable Teflon membrane. 
Regarding other materials utilized for external membranes, there are polyurethane membranes having hydrophobic and biocompatible properties (Chen et al. 2002, Yu et al. 2006), porous silicone membrane (Piechotta et al. 2005) and perfluorocarbons (Matsumoto et al. 2001). New type of membrane was created by mixing hydrophilic polyurethane (HPU) and its copolymer with polyvinylalcohol/ vinylbutyral (HPU/PVAB) with the optimum ratio HPU: PVAB for the determination of glucose in blood serum 3:2 (Han et al. 2007).

Phospholipid bilayers can be successfully used as a functional part of the sensor device for various groups of biological analytes (Albertorio et al. 2005). Phospholipid membranes are important for their two-dimensional fluidity, which allows the individual molecular constituents rearrange laterally similarly to the surface to the cell membrane. Supported bilayer provides effective protection against the nonspecific protein adsorption and biofouling. These systems are not used often in practical biosensor application. A serious disadvantage of their use is instability upon exposure to air.

Cell-based biosensor utilizing poly (3,4-ethylenedioxytiophene) (PEDOT) electrodes coated with Nafion and polylysine for combined conductivity, cellular adhesion and proliferation was reported (Flampouri and Kintzios 2011). The system was suggested to be a toxicity biosensor. Another effective modification of the platinum disc electrode (3 mm diameter) represents stable sandwich-type amperometric biosensor based on poly(3,4-ethylenedioxythiophene) (PEDOT) - single walled carbon nanotubes/ascorbate oxidase/Nafion film (Liu et al. 2011). Nafion was used as the outer film. Biosensor with relatively fast response (less than $10 \mathrm{~s}$ ) represents good platform for ascorbic acid detection with strong anti-interference ability against fructose, glucose, oxalic acid, nicotinic acid, sodium chloride, ethanol, etc., and excellent longterm stability.

A practical glucose biosensor was developed by combining the effect of $\mathrm{Fe}_{3} \mathrm{O}_{4}$ nanoparticles (NPs) and the anti-interference ability of the Nafion film (Yang et al. 2009). Glucose oxidase was simply mixed with $\mathrm{Fe}_{3} \mathrm{O}_{4} \mathrm{NPs}$, cross-linked on the Pt electrode surface by glutaraldehyde in chitosan medium, and then covered with a thin film of Nafion. The biosensor is characterized by very low detection limit $\left(6 \times 10^{-6}\right.$ mol. $\left.\mathrm{l}^{-1}\right)$, a very wide concentration range (from $6 \times 10^{-6}$ to $2.2 \times 10^{-3} \mathrm{~mol}^{-1} \mathrm{l}^{-1}$ ) and good storage stability. The effect of selected membranes such as cellulose acetate, chitosan, fibronectin, Nafion, and poly (styrene-sulphonate)/poly (L-lysine) against biofouling was studied also at the electrocatalytic reduction of dissolved oxygen at the gold electrode
(Trouillon et al. 2009). Fibronectin was found to be good in many cases.

Progressive design of an electrochemical glucose biosensor was shown by a Nafion/bacteria/ multiwalled-carbon-nanotube modified glassy carbon electrode (Liang et al. 2013). The biosensor utilizes Nafion membrane as the outer protective layer. Surplus sacharides containing d-galactose, $\mathrm{d}$-fructose, d-cellbiose, l-arabinose and d-sucrose, $\mathrm{d}$-maltose, d-mannose and d-xylose as well as common interfering substances (acetaminophen, ascorbic acid and uric acid) did not affect the detection of d-glucose. The biosensor is characterized by the high stability, specificity, reproducibility, simplicity, low price, and can be used for detection of real samples.

Very interesting work is a comparative study dealing with the most commonly used membranes such as glutaraldehyde - bovine serum albumin, glutaraldehyde vapour, Nafion and two nonstandard innovative systems based on $\mathrm{Ti}$ and $\mathrm{Pd}$ hexacyanoferrate hydrogels performed on the Pt electrodes modified by deposition of $\mathrm{Ni} / \mathrm{Al}$ hydrotalcite together with glucose oxidase (Mignani et al. 2009). Tests of interferences by ascorbic acids and acetaminophene (paracetamol) were the subject of the study. When Nafion is employed as the protective membrane, anionic analytes such as ascorbic acid display no interference.

Recently, the concept of outer-sphere membranes have been used in our laboratory at DNA based biosensors (Ziyatdinova and Labuda 2012). We have prepared biosensors by covering the DNA modified carbon electrode with the layer of Nafion and chitosan. Individual polymeric protection membranes have been found to be effective against biosensor fouling in matrices such as drinks (black tea, coffee, fruit juices, beer) and waters.

Rational modification of the platinum electrode was achieved by a mixture of Pt nanocubes, glucose oxidase and chitosan. A final coverage by Nafion led to the creation of ultrasensitive amperometric glucose biosensor which demonstrated excellent electrocatalytic activity especially with regard to the reduction and oxidation of $\mathrm{H}_{2} \mathrm{O}_{2}$ (Ren et al. 2012). The Nafion outer protective membrane eliminates the disturbance from interfering species such as ascorbic acid and uric acid.

To extend the linearity of sensor response and also to protect the biosensor, cross-linked poly(2hydroxyethyl methacrylate) external membrane was attached to the multilayered membranes formed at a platinum electrode by glucose oxidase and redox poly(allylamine) ferrocene was immobilized by layer-by-layer covalent attachment with the addition of Nafion with (Jusoh et al. 2012). Using this ex- 
ternal membrane, the biosensor protection against ascorbic acid and acetaminophen was significantly increased.
Techniques of construction and related properties of the external membranes are summarized in Table 1.

Tab. 1. Preparation and behaviour of some biosensor external membranes.

\begin{tabular}{|c|c|c|c|}
\hline Membrane & Preparation & Properties/mechanism & Ref. \\
\hline \multirow[t]{7}{*}{ Nafion } & $\begin{array}{l}\text { spin-coating, } 200 \mu \mathrm{l} \text { drop, electrode } \\
\text { rotated at } 1000 \mathrm{rpm} \text {. Nafion, solvent } \\
\text { evaporated by placing the electrode at } \\
200{ }^{\circ} \mathrm{C} \text { for } 2 \mathrm{~min} .\end{array}$ & $\begin{array}{l}\text { high affinity of Nafion with cations lead- } \\
\text { ing to a Donnan equilibrium }\end{array}$ & $\begin{array}{l}\text { Trouillon } \\
\text { et al. } 2009\end{array}$ \\
\hline & $\begin{array}{l}10 \mu \mathrm{l} \text { of a } 0.5 \% \text { dropped on the elec- } \\
\text { trode surface which was kept at room } \\
\text { temperature until dryness }\end{array}$ & $\begin{array}{l}\text { anionic analytes, such as ascorbic, uric and } \\
\text { citric acids display no interference }\end{array}$ & $\begin{array}{l}\text { Mignani } \\
\text { et al. } 2009\end{array}$ \\
\hline & Drop coating, air drying & $\begin{array}{l}\text { cation-exchange polymer, rejects nega- } \\
\text { tively charged components and biofouling, } \\
\text { improves biocompatibility }\end{array}$ & $\begin{array}{l}\text { Flampouri } \\
\text { and Kintzios } \\
2011\end{array}$ \\
\hline & $4 \mu \mathrm{l} 0.5 \%$ Nafion, drop coating & $\begin{array}{l}\text { excellent film forming ability, prevents } \\
\text { possible enzyme leakage, eliminates } \\
\text { anionic interferents }\end{array}$ & $\begin{array}{l}\text { Liu et al. } \\
2011\end{array}$ \\
\hline & $\begin{array}{l}\text { Electrode dipped into Nafion solution } \\
(2.5 \%, w / w) \text { and subsequently dried at } \\
\text { room temperature }\end{array}$ & $\begin{array}{l}\text { anti-interference coating and enzyme } \\
\text { immobilization matrix. }\end{array}$ & $\begin{array}{l}\text { Ren et al. } \\
2012\end{array}$ \\
\hline & $\begin{array}{l}3 \mu \mathrm{l} 0.1 \%(\mathrm{w} / \mathrm{v}) \text {, stored at } 4^{\circ} \mathrm{C} \text { when not } \\
\text { in use }\end{array}$ & $\begin{array}{l}\text { chemically and thermally inert, nonelec- } \\
\text { troactive, hydrophilic, and insoluble in } \\
\text { water }\end{array}$ & $\begin{array}{l}\text { Yang et al. } \\
2013\end{array}$ \\
\hline & $\begin{array}{l}10 \mu \mathrm{l} 0.05 \%(\mathrm{w} / \mathrm{w}) \text {, stored at } 4{ }^{\circ} \mathrm{C} \text { when } \\
\text { not in use }\end{array}$ & & $\begin{array}{l}\text { Liang et al. } \\
2013\end{array}$ \\
\hline Chitosan & $\begin{array}{l}5 \% \text { solution dropped on the electrode } \\
\text { surface and evaporated to dryness }\end{array}$ & $\begin{array}{l}\text { used typically in acidic and neutral media } \\
\text { allowing protonization of its amino } \\
\text { groups, membrane against high molecular } \\
\text { weight compounds }\end{array}$ & $\begin{array}{l}\text { Ziyatdinova } \\
\text { and Labuda } \\
2012\end{array}$ \\
\hline $\begin{array}{l}\text { Perfluoro- } \\
\text { carbon polymer } \\
\text { (PFCP) }\end{array}$ & $0.2 \%(\mathrm{w} / \mathrm{v})$ solution, spin-coating & $\begin{array}{l}\text { glucose diffusion limiting membrane, } \\
\text { immunity to interferences by ascorbic acid, } \\
\text { p-acetaminophen, and uric acid. }\end{array}$ & $\begin{array}{l}\text { Matsumoto } \\
\text { et al. } 2001\end{array}$ \\
\hline $\begin{array}{l}\text { Poly (hydroxy- } \\
\text { ethyl- } \\
\text { methacrylate) } \\
\text { pHEMA. }\end{array}$ & $\begin{array}{l}\text { G3P-8 Spin coater with a D6004 dis- } \\
\text { penser (Cookson Electronics } \\
\text { Speciality Coating Systems Inc, } \\
\text { Indianapolis), membrane layer soaked } \\
\text { in } 0.1 \text { mol.1 }{ }^{-1} \text { PBS pH } 6.7 \text { for } 48 \text { hours to } \\
\text { hydrate the pHEMA layer }\end{array}$ & $\begin{array}{l}\text { good mechanical strength, cross-linked } \\
\text { pHEMA hydrogels membranes exhibited } \\
\text { good protein rejection with small glucose } \\
\text { solute permeability, elimination of elec- } \\
\text { trochemical interferences such as ascorbic } \\
\text { acid and acetaminophen }\end{array}$ & $\begin{array}{l}\text { Jusoh et al. } \\
2012\end{array}$ \\
\hline \multirow[t]{2}{*}{ Polyurethane } & $\begin{array}{l}\text { Dip coating with } 3 \%(\mathrm{w} / \mathrm{w}) \text { solution in } \\
98 \% \text { tetrahydrofuran and } 2 \% \text { dimethyl- } \\
\text { formamide }(\mathrm{w} / \mathrm{w})\end{array}$ & $\begin{array}{l}\text { control of glucose and oxygen fluxes } \\
\text { in order to optimize linearity of sensor } \\
\text { response and minimize dependence on } \\
\text { oxygen tension }\end{array}$ & $\begin{array}{l}\text { Chen et al. } \\
2002\end{array}$ \\
\hline & $\begin{array}{l}1-1.5 \_\mu l 2.5 \%(w / v) \text { epoxy-poly- } \\
\text { urethane THF solution containing ca. } \\
40 \% \text { epoxy adhesive and curing agent } \\
\text { and ca. } 60 \% \text { polyurethane (wt.), to } \\
\text { avoid pinhole formation during solvent } \\
\text { evaporation, a } 5-10 \% \text { surfactant agent } \\
\text { (Brij } 30) \text { added }\end{array}$ & $\begin{array}{l}\text { polyurethane with phospholipid polar } \\
\text { groups and water-rich hydrogels have been } \\
\text { used to reduce tissue reactions, epoxy } \\
\text { resin adhesive enhanced durability of the } \\
\text { membrane for implantable biosensors }\end{array}$ & $\begin{array}{l}\text { Yu et al. } \\
2006\end{array}$ \\
\hline $\begin{array}{l}\text { Silicone } \\
\text { membrane }\end{array}$ & $\begin{array}{l}\text { pore membrane of } 12 \mu \mathrm{m} \text { thickness, } \\
\text { pores of } 5 \text { or } 10 \mu \mathrm{m} \text { diameter are etched } \\
\text { into the membrane }\end{array}$ & $\begin{array}{l}\text { minimization in number and size of the } \\
\text { pores allows only a small percentage of } \\
\text { molecules to diffuse through the pore } \\
\text { membrane inside the cavity, alternatively, } \\
\text { by using more or/and bigger pores, in- } \\
\text { creased diffusion rates into the cavity are } \\
\text { possible }\end{array}$ & $\begin{array}{l}\text { Piechotta } \\
\text { et al. } 2005\end{array}$ \\
\hline
\end{tabular}


Tab. 1. (continue) Preparation and behaviour of some biosensor external membranes.

\begin{tabular}{lll}
\hline Membrane & Preparation & Properties/mechanism \\
\hline Lipopolymer & $\begin{array}{l}\text { incorporation of poly(ethylene glycol) } \\
\text { phosphatidylethanolamine (PEG-PE) } \\
\text { lipopolymers } 30 \text { into supported lipid } \\
\text { membranes }\end{array}$ & $\begin{array}{l}\text { two-dimensional fluidity, which allows } \\
\text { the individual molecular constituents } \\
\text { to rearrange laterally just as they would } \\
\text { on the surface of a cell membrane, quite } \\
\text { resistant to nonspecific protein adsorption } \\
\text { and biofouling. }\end{array}$ \\
$\begin{array}{ll}\text { Cellulose } \\
\text { acetate }\end{array}$ & $\begin{array}{l}\text { spin-coating, } 200 \mu \text { l drop deposited on } \\
\text { the electrode immediately rotated at } \\
1000 \text { rpm }\end{array}$ & $\begin{array}{l}\text { in non-biofouling environments, it does } \\
\text { not protect the electrode surface from } \\
\text { protein adsorption, quite big pores, so } \\
\text { it is very likely that albumin permeates } \\
\text { through the membrane }\end{array}$ \\
& & Trouillon \\
\end{tabular}

\section{Conclusion}

The first biosensor was constructed more than fifty years ago. It was composed of the biorecognition element and transducer. This basic functional scheme remains true also today, but modern biosensors are much more intelligent, precise, selective, and compact. Years of extensive research and development activities together with experience in application of the biosensors provides a number of biocomponent immobilization methods, methods of interference prevention and methods for analyte transport control.

The complex chemical design of the biosensor building structure is typical feature of the biosensors today. Further development of such structure according to analytical purpose of special biosensor application can be expected in future. Of course, for wide use of the biosensors in practice, together with analytical parameters and application procedures, it is necessary to ensure their commercial production for sufficient low cost (D’Orazio 2011). Attractive properties of the electrochemical biosensors provide extreme perspectives for further improvement of efficiency of environmental screening, diagnostic testing, and therapy monitoring (Kimmel et al. 2012, Vyskočil et al. 2012). Today, the construction and production of biosensors start to apply microsystem technology resulting in miniature and portable devices. In the future, we can expect the production of even more integrated biosensoric system.

\section{Acknowledgement}

This publication was supported by the Competence Center for SMART Technologies for Electronics and Informatics Systems and Services, ITMS 26240220072, funded by the Research EDevelopment Operational Programme from the ERDF, and by the Slovak Research and Development Agency under the contract No. APVV-0797-11.

\section{References}

Akyilmaz E, Kozgus O, Türkmen H, Cetinkaya B (2010) Bioelectrochemistry 78: 135-140.

Albertorio F, Diaz AJ, Yang T, Chapa VA, Kataoka S, Castelana ET, Cremer PS (2005) Langmuir 21, 7476-7482.

Alp B, Mutlu S, Mutlu M (2000) Food Research International 33: 107-112.

Badea M, Curuli A, Palleschi G (2003) Biosensors and Bioelectronics 18: 689-698.

Berners MO, Boutelle MG, Fillenz M (1994) Analytical Chemistry 66: 2017-2021.

Carelli I, Chiarotto I, Curulli A, Palleschi G (1996) Electrochimica Acta 41: 1793-1800.

Centonze D, Guerrieri A, Malitesta C, Palmasino F, Zambonin PG (1992) Journal of Analytical Chemistry 342: 729-733.

Centonze D, Zambonin PG, Palmasino F (1997) Journal of AOAC International 80: 829-833.

Chen X, Hu Y, Wilon GS (2002) Biosensors and Bioelectronics 17: 1005-1013.

Daly DJ, O'Sullivan CK, Guibault GG (1999) Talanta 49: $667-678$.

Dong-Hun J, Yong-Sup Y, Seung, MO (1995) Bulletin of the Korean Chemical Society, 16: 392-397.

D'Orazio P (2011) Clinica Chimica Acta 412: 1749-1761.

Garcia CAB, Oliveira Neto G, Kubota LT (1998) Analytica Chimica Acta 374, 201-208.

Guerriri A, Benedett GE, Palmasino F, Zambonin PG (1998) Biosensors and Bioelectronics 13: 103-112.

Han JH, Taylor JD, Kim DS, Kim YS, Kim YT, Cha GS, Nam H (2007) Sensors and Actuators B: Chemical 123: 384-390.

Flampouri E, Kintzios S (2011) Procedia Engineering 25: 976-979.

Ioannis D, Karalemas A, Constantinos A, Georgiou B, Demetrius S, Papastathopoulos A (2000) Talanta 53: 391-402.

Jusoh N, Aziz AA, Supriyanto E (2012) International Journal of Biology and Biomedical Engineering 1 (6): 77-86.

Kimmel DW, LeBlanc G, Meschievitz ME, Cliffel DE (2012) Analytical Chemistry 84, 685-707. 
Koh WCA, Son J, Choe ES, Shim Yoon-Bo (2010) Analytical Chemistry 82 (24): 10075-10082.

Labuda J (2012) In: Electrochemical DNA Biosensors, Ed. M. Ozsoz, pp. 1-27. ISBN: 9789814241779, Pan Stanford Publishing Pte. Ltd.

Liang B, Li L, Tang X, Lang Q, Wang H, Li F, Shi J, Shen W, Palchetti I, Mascini M, Liu A (2013) Biosensors and Bioelectronics 45 (1): 19-24.

Liu M, Wen Y, Li D, Yue R, Xu J, He H (2011) Sensors and Actuators B 159: 277-285.

Madaras MB, BUCK RP (1996) Analytical Chemistry 68: 3832-3839.

Marzouk SAM, Cosorfet VV, Buck RP, Yang H, Cascio WE, Hassan, SSM (1997) Talanta 44: 1527-1541.

Matsumoto T, Ohashi A, Ito N, Fujiwara H, Maramuoto T (2001) Biosensors and Bioelectronics 16: 271-276.

McGrath TF, Elliott CT, Fodey TL (2012) Analytical and Bioanalytical Chemistry 403: 75-92.

Miao Y, Chen J, Wu X (2004) Trends in Biotechnology 22: 227-231.

Mignani A, Scavetta E, Guadagnini L, Tinelli D (2009) Sensors and Actuators B 136: 196-202.

Mulyasuryani A, Roosdiana A, Srihardyastutie A (2010) Indo. J. Chem. 10: 162-166.

Murphy LJ (1998) Analytical Chemistry 70: 2928-2935.

Palmasino F, Cantonze D, Guerrieri A, Zambonin PG (1993) Biosensors and Bioelectronics 8: 393-399.

Petřivalsky M, Skládal P, Macholán L, Volc J (1994) Collection Czechoslovak Chemical Communication 59: $1226-1234$.

Piechotta G, Albers J, Hintsche R (2005) Biosensors and Bioelectronics 21: 802-808.

Poyrda S, Jaffrezic-Renault N, Martelet C, Cosnier S, Labble P (1998) Analytica Chimica Acta 364: $165-172$.
Ren J, Shi W, Li K, Ma Z (2012) Sensors and Actuators B 163: $115-120$

Somasundrum M, Aoki K (2002) Journal of Electroanalytical Chemistry 530: 40-46.

Thevenot DR, Toth K, Durst RA, Wilson GS (1999) Pure and Applied Chemistry 71: 2333-2348.

Trouillon R, Combs Z, Patel BA, . O'Hare D (2009) Electrochemistry Communications 11: 1409-1413.

Vidal JC, Espersnza G, Castillo JR (1999) Analytica Chimica Acta 385: 213-222.

Vyskočil V, Blašková M, Hájková A, Horáková E, Krejčová Z, Stávková K, Wang J (2012) Sensing in Electroanalysis 7: 141-162

Wang J, Chen l, Hocevar SB, Ogorevc B (2000) Analyst 125: $1431-1434$

Xu JJ, Yu ZH, Chen HY (2002) Analytica Chimica Acta 463: 239-247.

Yang L, Wang GC, Liu YJ, An JJ, Wang M (2013) Analytical and Bioanalytical Chemistry 405 (8): 2545-2552.

Yang L, Ren X, Tang F, Zhang L (2009) Biosensors and Bioelectronics 25: 889-895.

Yang Q, Atanasov P, Wilkins E (1999) Biosensors and Bioelectronics 14: 203-210.

Yao T, Yano T, Nanjyo Y, Nishino H (2003) Analytical Science 19: 61-64.

Yu B, Long N, Moussy Y, Moussy F (2006) Biosensors and Bioelctronics. 21: 2275-2282.

Zajancová L, Pospíšková K (2009) Chemické Listy 103: 291-301.

Ziyatdinova G, Labuda J (2012) Electroanalysis 24: 2333-2340.

Zu Y, Liu H, Zhang Y, Hu N (2009) Electrochimica Acta 54: 2706-2712. 